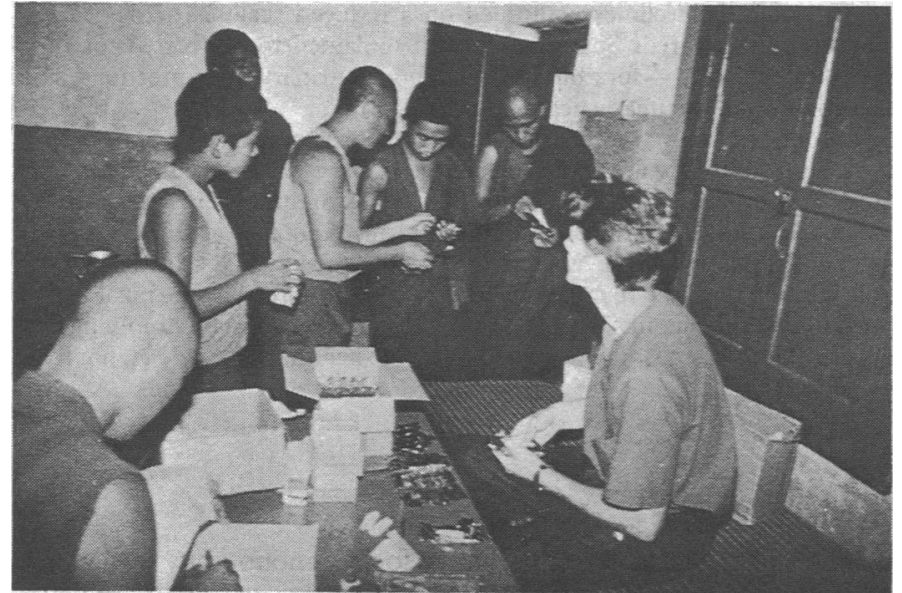

At the clinic during the mass treatment programme.

principal for his. They belonged to the same breed, possessed the same ethos. Giants among young minds, moulding with the same fundamental principles, they would have recognised each other.

My aim was to find simple methods of prevention that would continue to effect change long after I left. The primary health care that we established is part of a long term project to ensure that these people can continue to impart their unique knowledge. They have an enormous amount to contribute to the world.

I intend to return on a regular basis. Leaving Ganden was the hardest thing that I have ever done; I had been there long enough to have an existence. After 21 years of continuous education it was the first time that I had put that learning into use.
The following quotations illustrate the fundamental principles of our work in Ganden.

"We must teach the students how to collect the facts, to verify them, to assign a value to them, and how to draw conclusions from them and test those conclusions; in short, how to form a judgment.... The true aim of the teacher should be to impart an appreciation of method rather than a knowledge of facts, for method is remembered when facts have been forgotten, and method can be used in a new situation where there are no, or too few, facts."

"If a time of scanty resources brings out inner truth, one must not feel ashamed of simplicity. For simplicity is the very thing needed to provide the inner strength for further undertakings. Indeed there need be no concern if the outward beauty of civilisation or of religious forms should have to suffer because of simplicity-one must draw on the strength of the inner attitude to compensate for what is lacking in externals. Then the power of the content makes up for the simplicity of the form." (From the I Ching Hexogram 43.)

I should like to thank Dr Francis Sully, who created the programme; my classmates, who attended our fund raising party; Vincent Kenny and ICROSS, who are funding the programme as a long term project; the Oxford Union charities fund; and Professor Denis Gill and Dr Eoin O'Brien for encouraging me to write this article.

\section{Reference}

1 Pickering G. Medicine's challenge to the educator. Br Med f 1958;ii:1117-21.

Dublin 16, Ireland

KIERAN MURPHY, $\mathrm{MB}, \mathrm{BCH}$, house officer

Correspondence to: 32 Knockaire, Knocklyon Road, Dublin 16, Ireland.

\title{
Scott: 75 years on
}

\author{
MICHAEL STROUD
}

This winter marks the 75th anniversary of Robert Scott's epic walk to the South Pole. It was on their return that he and his four companions perished through cold and poor nutrition. Much has been written and televised recently denigrating the man for his planning and character. But it is easy to criticise in hindsight and to forget the conventions of the era that bound Scott to a rigid code of practice. Additionally, so far as I know, none of the critics have actually experienced a lengthy polar journey using machines or dogs, let alone attempted to plan or undertake a manhauling journey to either pole.

Last year I was fortunate enough to be the expedition doctor with the three man team that repeated Scott's route to the South Pole, and although not on the polar trip itself I was intimately concerned with its planning and the many training trips that occurred during a one year stay on the very beach that Scott had lived on in 1911-2. I also attempted to manhaul to the North Pole with Sir Ranulph Fiennes, and I believe that these two experiences make me better qualified than most to comment on Scott's planning and character.

\section{London SW2 5TA}

MICHAEL STROUD, MRCP, honorary research fellow

Correspondence to: 18 Concanon Road, Brixton, London SW2 5TA.

\section{Lambasted for logistical mistakes}

Scott has been lambasted for his mistakes in logistics, with little account taken of how difficult it is to plan for the unknown. Sure enough, he was an amateur when compared with Amundsen, and beyond doubt he failed to see some of the lessons that could have been learnt from the Norwegian. Nevertheless, he took on a mammoth task and, despite his means of transport being far from the best and his nutrition being hopelessly inadequate, he actually covered more than 1500 miles of his $\mathbf{1 7 0 0}$ mile journey. If luck had been a little less unkind he would have succeeded.

Last year's trip to the pole was only one way, but it still took the three men 70 days to cover the 875 miles of unbroken ice. In temperatures down to $-35^{\circ} \mathrm{C}$ each man pulled sledges weighing 155 $\mathrm{kg}$, slightly more than that pulled by each man in Scott's party. They consumed an energy dense daily ration that weighed only $970 \mathrm{~g}$ uncooked yet provided about $21 \mathrm{MJ}(5000 \mathrm{kcal})$. Over the journey the men lost between 6.7 and $10.5 \mathrm{~kg}$, and from these figures and their energy intake an average daily energy expenditure of nearly 25 MJ $(6000 \mathrm{kcal})$ was calculated. This corresponded well with estimates of their energy output made using a diary card method, in which the time spent each day in different categories of activity was recorded and each category was assigned a value based on previous reports on energy expenditure.

Although a discrepancy between Scott's energy intake and output 
has been noted before-his diet has been estimated as providing an average of about $16.7 \mathrm{MJ}(4000 \mathrm{kcal})$ with estimates for energy expenditure of about $21 \mathrm{MJ}(5000 \mathrm{kcal})$ a day-it has always been thought that the most important nutritional factor in his party's demise was a lack of vitamins, particularly vitamin B and vitamin C. Since our expedition's journey was over the same route as Scott's, pulling similar weights and at the same time of year, I think it is likely that this discrepancy has been grossly underestimated and that sheer starvation with consequent emaciation might have been the more important factor. For example, Evans, the biggest man in Scott's team, may have lost over $15 \mathrm{~kg}$ by the time that he reached the pole, before even starting the return journey.

It is interesting that even with today's knowledge of nutrition and the experienced advice that we received the size of our nutritional deficit came as something of a surprise. It makes me wonder how fair it is to blame Scott for his poor provisioning.

\section{Unfair character assassination}

There have been several vicious attempts at character assassination that have portrayed Scott as a hopeless leader. Certainly, by today's standards he was rigid in his thinking, particularly when it came to segregation of officers and men. But in making judgments such as these we must view him as a product of the previous decades of British naval tradition and not blame him, as if it were a personal failing, for following his upbringing.

The pressures that a sledging trip exert have to be experienced to be believed. The inevitable exhaustion, the claustrophobia of a tent, and the intense discomfort of the cold combine to give an ideal breeding ground for disharmony. With a little digging and some use of the imagination it is not surprising that it is possible to come up with difficulties between Scott and his party, and indeed I am surprised that there is no evidence of greater problems. The fact that many of the men from his earlier Discuvery expedition, including the widely revered Dr Edward Wilson, were prepared to follow him again should not be ignored.

It has been said that Scott was ambitious but that he was also a weak, indecisive man who hated the environment that has been so solidly linked to his name. Once again, personal experience of polar sledging makes me doubt this judgment. You only have to set out towards the empty white horizon, struggling with every step, to realise the depths of determination required to take a man to the most inaccessible place on earth. I sincerely believe that mere ambition is not enough and that however much you hate the place at times you cannot cross it without a paradoxical passion for its stark, pure beauty.

Scott was probably not the perfect hero that Edwardian England created, but I very much doubt that he was the weak willed fool that some would have us believe.

\title{
Priests and polio: research in a warmhearted climate
}

\author{
H V WYATT
}

It seemed an easy thing to do: the 400 Maltese children who caught polio in the great epidemic of 1942 would be between 40 and 45 years old and I would go and find them. Malta is a small island, the Maltese friendly and speak English. The British Polio Fellowship provided me with the name and address of the secretary of the rehabilitation centre in Malta and the Peel Medical Research Trust gave me a grant for a three week visit. My college had an annual field trip for the geographers which I could join. I was put in touch with the chief government pharmacist who was incidently a member of my own professional body. Then came the university cuts: no more department, no geographers' trip, but premature retirement made the best of a bad job. Exchange Holidays had a cheap bed and breakfast holiday, so we left for the sun.

The first thing was to find any records. The Ministry of Health is housed in one of the fine old Baroque buildings in the centre of Valletta, originally the Court of Justice of the Knights-together with the cells for their detention. In one of these cells are kept the records of infectious diseases but unfortunately the polio records from 1920 to 1952 became mouldy and were thrown away. But I had the names, addresses, and ages of the patients from 1953 to the last one in 1964. Then my luck started. I began telephoning all the doctors who had written the $B M \mathcal{F}$ papers on the outbreak or had been thanked in the acknowledgments. Dr Albert Bartolo, the orthopaedic surgeon-Bones Bartolo to the Maltese-had the case notes of 260 of the patients whom he had seen or operated on since 1942. Some of the notes were detailed, others no more than a name. Then I was introduced to Mrs Damato, the first Maltese physiotherapist. Yes, there was a drawer of case notes in an old filing

Department of Community Medicine, University of Leeds, Leeds LS2 9JT H V WYATT, PHD, FIBIOL, honorary research fellow cabinet in the department. There were about a thousand case notes relating to several hundred cases and an alphabetical list with more names and some addresses.

By this time a short article about my search had appeared in The Times of Malta and I had given an interview on Radio Malta. Only 10 people got in touch with me but one was a well known singer who took us out for an evening of Maltese music and folk dancing. When we left at the end of our three week reconnaissance I had about 600 cards, which I sorted in the arrivals lounge of Gatwick Airport between 1 am and 6 am with mounting excitement.

After six months' teaching in the Middle East we returned to Malta: the University Grants Committee cuts had given me time if not money. I was welcomed by the Ministry of Health and the medical school. Although the medical profession in Malta has been riven by the aftermath of the doctors' strike, I have met only kindness and help. On a visit to the lovely sister island of Gozo I examined the infectious diseases register from 1927 and found the names of just over 100 polio victims from Gozo-the biggest gap in my records up to that time. We now lived in a lovely flat in the centre of Malta - the old stables of a grand palace with flowers and trees outside our window and a donkey to give our orange peel to. It was summer again.

\section{Records abandoned in a cupboard}

At a clinical meeting I mentioned my work and was told that the ledgers of the old isolation hospital had been left in a cupboard in the now abandoned Lazarreto. This was the old plague quarantine building-imprisonment with the chance of catching plague as Byron put it. The beautiful arches face the huge walls of Valletta across the creek from Manoel Island. During the second world war it was the submarine base and heavily bombed, but from 1947 to 1978 it returned to being the isolation hospital. The ledgers-heavy 